\title{
Prosthecomicrobium litoralum, a New Species from Marine Habitats
}

\author{
JOHN BAULD, $\dagger$ ROBERT BIGFORD, AND JAMES T. STALEY* \\ Department of Microbiology and Immunology, University of Washington, Seattle, Washington 98195
}

\begin{abstract}
Marine strains of multiply appendaged prosthecate bacteria have been isolated. All three strains included in this study have characteristics that are typical of the genus Prosthecomicrobium. The deoxyribonucleic acid base compositions of the strains tested range from 66 to $67 \mathrm{~mol} \%$ guanine plus cytosine; these values are similar to the value reported for Prosthecomicrobium enhydrum. However, the new strains which we studied differ from Prosthecomicrobium enhydrum because of their marine origin, immotility, requirement for a minimum salinity for growth of $5 \%$, and lack of colony pigmentation. The marine strains have an absolute sodium ion requirement for growth, which is consistent with their being indigenous to marine environments. A new species, Prosthecomicrobium litoralum, is proposed.
\end{abstract}

Most prosthecate bacteria have been isolated from freshwater sources, although representatives of caulobacters and hyphomicrobia have been reported from marine habitats. Two species of the genus Caulobacter, Caulobacter maris and Caulobacter halobacteroides, are of marine origin (8), and one species of the Hyphomicrobium group, "Hyphomonas neptunium" (formerly designated Hyphomicrobium neptuni$u m)$, has been isolated from seawater $(4,5)$. More recently, additional strains of "Hyphomonas" spp. have been isolated from Pacific hydrothermal vents. To our knowledge, marine strains of the prosthecate genera Prosthecomicrobium and Ancalomicrobium have not been reported previously. It is true that multiply appendaged bacteria resembling members of these genera have been obtained from brackish and marine samples $(6,7)$, but the appendages of these organisms are not bound by the cell walls of the organisms as prosthecae are; instead, they are composed entirely of protein and are, therefore, structurally and chemically analogous to pili $(2,3)$. Thus, these nonprosthecate bacteria are very different from Prosthecomicrobium and Ancalomicrobium (9). The objective of this study was to determine whether marine strains of multiply appendaged prosthecate bacteria could be isolated.

\section{MATERIALS AND METHODS}

The enrichment and isolation procedures which we used have been described previously in detail by Staley and Bauld (10) for Planctomyces maris, with

† Present address: Baas Becking Geobiological Laboratory, Canberra City, A.C.T. 2601, Australia. the following exception. A number of sample localities supported dense populations of Ulva spp., and in such cases enrichment cultures in media containing dilute peptone (final concentration, $0.01 \%$, wt $/$ vol) were established both with and without small Ulva fronds. The media used and the procedures adopted for all physiological investigations, light microscopy, and electron microscopy have been fully described by Bauld and Staley (1). Any variations in these methods are noted below.

\section{RESULTS}

Enrichment and isolation of strains. Three multiply appendaged bacteria were successfully enriched and axenically cultivated from littoral marine waters from the Oregon and Washington coastlines (Table 1). In two of the three samples, enrichment of the organisms was achieved when small pieces of Ulva fronds, which were found on rocks in the sampling areas, were included in the initial dilute peptone enrichment medium.

Morphology. The three strains used in this investigation had overall morphological features that were typical of the genus Prosthecomicrobium. Cells observed by phase-contrast microscopy appeared to be short to long rods about 1.0 $\mu \mathrm{m}$ diameter (Fig. 1). The most distinctive feature noticeable by phase-contrast microscopy was the irregular surfaces of the cells, which imparted somewhat fuzzy outlines to the cells. Occasional cells, particularly cells of the Tillamook Bay strain (strain 511-2B1), had one or more much longer prosthecae that could be readily recognized (Fig. 2). All three strains were gram negative.

Numerous individual prosthecae were readily apparent when whole cells of the three strains were examined by electron microscopy (Fig. 3). 
TABLE 1. Sources and selected characteristics of Prosthecomicrobium litoralum strains

\begin{tabular}{|c|c|c|c|}
\hline \multirow{2}{*}{ Property } & \multicolumn{3}{|c|}{ Prosthecomicrobium litoralum strain: } \\
\hline & $511-2 \mathrm{~B} 1$ & $520-5 \mathrm{~A} 3$ & $524-16^{\mathrm{T}}$ \\
\hline Field sample locale & $\begin{array}{l}\text { Tillamook Bay, Oregon; } \\
\text { enclosed bay between } \\
\text { Garibaldi and Bay City } \\
\text { on Highway } 101\end{array}$ & $\begin{array}{l}\text { Richmond Beach, Puget } \\
\text { Sound, north King } \\
\text { County, Washington }\end{array}$ & $\begin{array}{l}\text { Point Lowell, Camano Island } \\
\text { State Park, Puget Sound } \\
\text { Washington State Park }\end{array}$ \\
\hline Sample description & $\begin{array}{l}\text { Seawater near rocks, } \\
\text { with Ulva added; } \\
11.0^{\circ} \mathrm{C} ; \text { surface } \\
\text { sample; } 29 \mathrm{July} 1973\end{array}$ & $\begin{array}{l}\text { Shoreline seawater; } 15.0^{\circ} \mathrm{C} \text {; } \\
\text { depth, ca. } 1 \mathrm{~m} ; 14 \\
\text { August } 1973\end{array}$ & $\begin{array}{l}\text { Shoreline seawater, Ulva } \\
\text { from rocks included; } 27 \\
\text { August } 1973\end{array}$ \\
\hline Morphology & $\begin{array}{l}\text { Short appendages }(<1.0 \\
\mu \mathrm{m}) ; \text { nonmotile }\end{array}$ & $\begin{array}{l}\text { Short appendages }(<1.0 \\
\mu \mathrm{m}) ; \text { nonmotile }\end{array}$ & $\begin{array}{l}\text { Short appendages }(<1.0 \\
\mu \mathrm{m}) ; \text { nonmotile }\end{array}$ \\
\hline $\begin{array}{l}\text { Optimum temp range } \\
\text { (doubling time) }^{a}\end{array}$ & $24-30^{\circ} \mathrm{C}(11-13.5 \mathrm{~h})$ & $26-35^{\circ} \mathrm{C}(10-12 \mathrm{~h})$ & $26-35^{\circ} \mathrm{C}(10-12 \mathrm{~h})$ \\
\hline $\begin{array}{l}\text { Shortest doubling } \\
\text { time (temp) }\end{array}$ & $10 \mathrm{~h}\left(26^{\circ} \mathrm{C}\right)$ & $10 \mathrm{~h}\left(34^{\circ} \mathrm{C}\right)$ & $10 \mathrm{~h}\left(31^{\circ} \mathrm{C}\right)$ \\
\hline $\begin{array}{l}\text { Minimum growth } \\
\text { temp }^{a, b}\end{array}$ & $5^{\circ} \mathrm{C}$ & $1^{\circ} \mathrm{C}$ & $5^{\circ} \mathrm{C}$ \\
\hline $\begin{array}{l}\text { High-temp } \\
\text { response } e^{a, c}\end{array}$ & $\begin{array}{l}\text { No growth at } 38^{\circ} \mathrm{C} \text {; slight } \\
\text { growth at } 34^{\circ} \mathrm{C}\end{array}$ & Slight growth at $39^{\circ} \mathrm{C}$ & Slight growth at $39^{\circ} \mathrm{C}$ \\
\hline $\begin{array}{l}\text { Salinity optimum } \\
\text { (range) }\end{array}$ & $25 \%(5-45 \%)$ & $25 \%$ oo $(10-35 \%)$ & $25 \%(5-35 \%)$ \\
\hline
\end{tabular}

${ }^{a}$ Determined by using static cultures in screw-cappped tubes in a temperature gradient aluminum block. The cultures were hand shaken once daily. Medium B-SW of Bauld and Staley (1) was used, growth was measured by determining optimal densities at $560 \mathrm{~nm}$.

${ }^{b}$ Based on a fivefold increase in absorbance at $560 \mathrm{~nm}$ after 18 days at the temperature specified.

${ }^{c}$ Slight growth was defined as a threefold increase in absorbance at $560 \mathrm{~nm}$ within 7 days.

The prosthecae were usually short (i.e., less than $1.0 \mu \mathrm{m}$ long) and tapered toward their tips. However, some appendages occasionally exceeded $2.0 \mu \mathrm{m}$ in length, a characteristic which has been also reported for Prosthecomicrobium pneumaticum.

Motility was not observed for any of the marine isolates. Likewise, gas vacuoles were not observed.

Physiological properties. The general physiological properties of the isolates are summarized in Table 1. The isolates were heterotrophic and mesophilic, with optimum growth temperatures

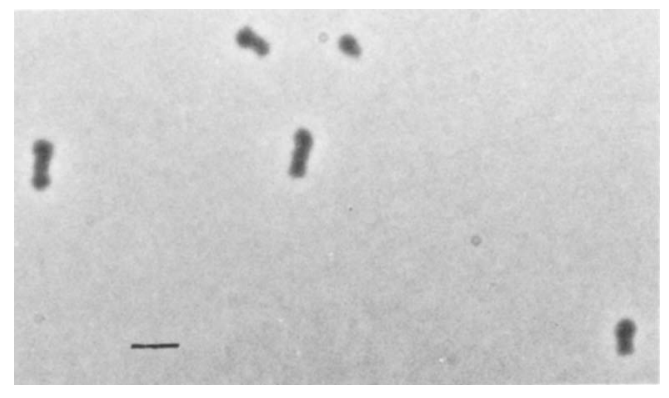

FIG. 1. Phase-contrast photomicrograph of Prosthecomicrobium litoralum strain $524-16^{\mathrm{T}}$. Note the somewhat irregular outlines of the cells due to the numerous short prosthecae. Bar $=2.0 \mu \mathrm{m}$. ranging from ca. 25 to $35^{\circ} \mathrm{C}$. All three strains grew slowly at refrigerator temperatures (ca. $4^{\circ} \mathrm{C}$ ), suggesting that they may be able to grow throughout the year in the northern Pacific habitat in which they were found. The minimum doubling times of $10 \mathrm{~h}$ were relatively long compared with the $6.3 \mathrm{~h}$ reported for Prosthecomicrobium enhydrum (9).

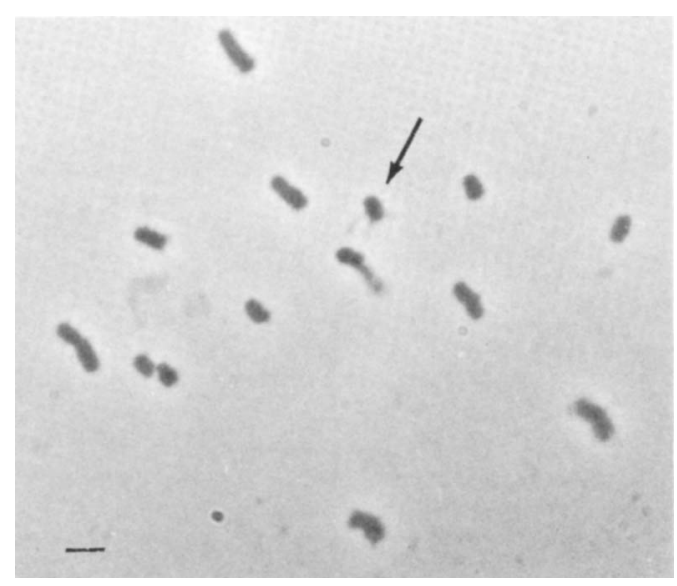

FIG. 2. Phase-contrast photomicrograph of Prosthecomicrobium litoralum strain 511-2B1. This strain typically produces longer prosthecae (arrow) in addition to shorter prosthecae. $\mathrm{Bar}=2.0 \mu \mathrm{m}$. 


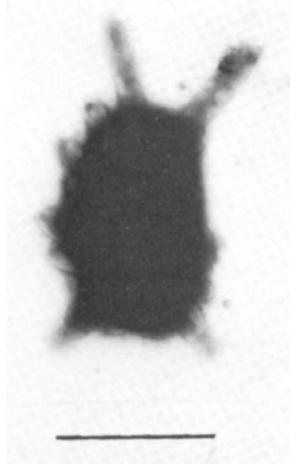

FIG. 3. Negatively stained electron micrograph of Prosthecomicrobium litoralum strain 524-16 ${ }^{\mathrm{T}}$. Bar $=$ $1.0 \mu \mathrm{m}$.

The range of salinity tolerance for growth was moderately wide, with an optimum salinity of $25 \%$. The greatest salinity range ( 5 to $40 \%$ oo was exhibited by strain 511-2B1, which was isolated from the waters of an enclosed marine embayment that is subjected to seasonal salinity variations. None of the strains grew in media devoid of sodium ions even though full sodium ion osmolarity of an artificial marine salts solution was compensated for with potassium chloride. Strains $520-5 \mathrm{~A} 3$ and $524-16^{\mathrm{T}}$ (type strain) showed some growth in the presence of $50 \mathrm{mM}$ sodium chloride, and strain 511-2B1 grew slightly in the presence of $100 \mathrm{mM}$ sodium chloride when salinity was corrected for with potassium chloride. Optimum growth for all strains occurred when the sodium chloride concentration was between 150 and $470 \mathrm{mM}$, irrespective of the potassium ion concentration.

Carbon source utilization. The utilization of various carbon sources by the three strains which we studied was tested (Table 2) and compared with the utilization of carbon sources by Prosthecomicrobium enhydrum and Prosthecomicrobium pneumaticum as reported by Staley (9). In contrast to the other two marine strains, strain 511-2B1 did not use maltose, rhamnose, or trehalose. Some differences in the utilization of sugar alcohols were also observed. With the exception of strain 511-2B1, the marine strains used all of the sugar alcohols tested. This pattern was similar to the pattern observed in Prosthecomicrobium pneumaticum, but differed markedly from the pattern observed in Prosthecomicrobium enhydrum, which did not use any of these compounds as carbon sources.

All three strains grown on plates containing medium B-SW supplemented with glucose (final concentration, $0.1 \%$ ) as a carbon source showed slight agar digestion after incubation at 20 to $25^{\circ} \mathrm{C}$ for 30 to 60 days. Although we are not aware that this has been reported previously for other prosthecate bacteria, strains of Ancalomicrobium and Caulobacter are known to hydrolyze this polysaccharide.

DNA base composition. The deoxyribonucleic acid (DNA) base compositions of two of the isolates, strains $520-5 \mathrm{~A} 3$ and $524-16^{\mathrm{T}}$, were determined by using the $\mathrm{CsCl}$ buoyant density procedure. Strain 520-5A3 had a guanine-andcytosine content of $66 \mathrm{~mol} \%$, whereas the value for strain $524-16^{\mathrm{T}}$ was $67 \mathrm{~mol} \%$.

\section{DISCUSSION}

Our results demonstrate that marine strains of Prosthecomicrobium do exist. The strains which we isolated have all of the major properties of the genus Prosthecomicrobium; all are prosthecate bacteria that contain the numerous short prosthecae which are characteristic of this genus. In addition, they resemble bacteria in the genus Prosthecomicrobium in their overall carbon source utilization patterns and other general physiological properties, such as optimum growth rate and temperature optimum. Furthermore, the range of their DNA base compositions ( 66 to $67 \mathrm{~mol} \%$ guanine plus cytosine) is consistent with the values that have been obtained for the genus Prosthecomicrobium.

However, our isolates are not identical to any known Prosthecomicrobium species. In contrast to previously described species of the genus, but consistent with their marine origin, our strains have an obligate growth requirement for sodium ions. Moreover, they cannot grow at salinity levels less than $5 \%$. They also differ in other respects from the previously described species of Prosthecomicrobium, Prosthecomicrobium enhydrum and Prosthecomicrobium pneumaticum). For example, Prosthecomicrobium enhydrum cells are motile by single polar to subpolar flagella, whereas the cells of the marine strains are nonmotile. In addition, Prosthecomicrobium enhydrum produces a yellow pigment, whereas the marine strains are nonpigmented. Prosthecomicrobium pneumaticum is immotile like the marine strains, but it produces gas vacuoles, which are not formed by any of the marine strains included in our investigation. Furthermore, the guanine-plus-cytosine contents of the marine strains are lower than those of Prosthecomicrobium pneumaticum (11).

Because of these major differences between the marine strains of Prosthecomicrobium and the currently accepted species, we conclude that a new species should be established in the genus. We propose to name this species Prosthecomicrobium litoralum; this new species is described below. 
TABLE 2. Carbon source utilization by strains of Prosthecomicrobium litoralum and the type strains of Prosthecomicrobium enhydrum and Prosthecomicrobium pneumaticum ${ }^{a}$

\begin{tabular}{|c|c|c|c|c|c|}
\hline \multirow[b]{2}{*}{ Carbon source ${ }^{b}$} & \multicolumn{5}{|c|}{ Utilization by strain: } \\
\hline & $511-2 \mathrm{~B} 1$ & $524-16^{\mathrm{T}}$ & $520-5 \mathrm{~A} 3$ & $\begin{array}{l}\text { P. enhydrum } \\
\text { ATCC } 23634^{\mathrm{T}}\end{array}$ & $\begin{array}{c}\text { P. pneumaticum } \\
\text { ATCC } 23633^{\mathrm{T}}\end{array}$ \\
\hline Arabinose & $+c$ & + & + & + & + \\
\hline Cellobiose & + & + & + & + & + \\
\hline Fructose & + & + & + & + & + \\
\hline Fucose & + & + & + & + & + \\
\hline Galactose & + & + & + & + & + \\
\hline Glucose & + & + & + & + & + \\
\hline Lactose & + & + & + & + & + \\
\hline Maltose & - & + & + & + & + \\
\hline Mannose & + & + & + & + & + \\
\hline Melibiose & - & - & - & - & + \\
\hline Raffinose & - & - & - & - & - \\
\hline Rhamnose & - & + & + & + & + \\
\hline Ribose & + & + & + & + & + \\
\hline Sucrose & + & + & + & NT & NT \\
\hline Trehalose & - & + & + & NT & NT \\
\hline Furanose & + & + & + & NT & NT \\
\hline Xylose & + & + & + & + & + \\
\hline Adonitol & - & + & + & - & + \\
\hline Arabitol & + & + & + & - & - \\
\hline Dulcitol & - & + & + & - & + \\
\hline Erythritol & - & + & + & - & - \\
\hline Ethanol & - & - & - & - & + \\
\hline Glycerol & + & + & + & - & + \\
\hline Inositol & + & ND & + & - & + \\
\hline Mannitol & + & + & + & - & + \\
\hline Sorbitol & - & + & + & - & + \\
\hline Sodium acetate & + & + & + & NT & NT \\
\hline Sodium benzoate & - & - & - & - & - \\
\hline Sodium fumarate & - & - & - & + & - \\
\hline Sodium glucuronate & + & - & - & NT & NT \\
\hline Sodium $\beta$-hydroxybutyrate & + & + & + & NT & NT \\
\hline Sodium lactate & + & + & + & NT & NT \\
\hline Sodium malate & + & + & + & NT & NT \\
\hline Sodium propionate & - & - & - & $?$ & + \\
\hline Sodium pyruvate & + & + & + & NT & NT \\
\hline Sodium succinate & + & + & - & + & - \\
\hline Gelatin & - & - & - & NT & NT \\
\hline Glycine & - & - & - & NT & NT \\
\hline Pectin & - & - & - & - & - \\
\hline Urea & - & - & - & NT & NT \\
\hline $\operatorname{Agar}^{d}$ & + & + & + & NT & NT \\
\hline
\end{tabular}

${ }^{a}$ See reference 9.

${ }^{b}$ The carbon sources were in $2 \%(\mathrm{wt} / \mathrm{vol})$ solutions; the final concentration of carbon source in each experiment was $0.1 \%$. See reference 1 for methodology.

${ }^{c}+$, Carbon source utilized; -, carbon source not utilized; ?, utilization uncertain; ND, no data; NT, not tested.

${ }^{d}$ Colonies developed recessed areas when they were grown for 1 month or more on medium B-SW.

Prosthecomicrobium litoralum sp. nov. Prosthecomicrobium litoralum (li.to.ra'lum. L. adj. litoralis of the seashore) cells are short to long rods (diameter, ca. $1.0 \mu \mathrm{m}$ ) with numerous tapering prosthecae. Most prosthecae are short (i.e., less than $0.5 \mu \mathrm{m}$ long), although occasional prosthecae are longer. Gas vacuoles are not produced. Nonmotile. Colonies are white and raised initially, becoming cream colored and umbonate after prolonged incubation.

Sodium ions are required for growth. The minimum salinity for growth is $5 \%$ oo the optimum salinity $25 \%$. The optimum temperature for growth is 27 to $34^{\circ} \mathrm{C}$.

The guanine-plus-cytosine content of the DNA ranges from 66 to $67 \mathrm{~mol} \%$, as determined by buoyant density (two strains tested).

Description of the type strain. The type strain 
of the species is strain 524-16. This strain has been deposited in the American Type Culture Collection as ATCC 35022 and has all of the properties described above for the species. Additional properties are given in Tables 1 and 2 .

The observation that all of the strains of Prosthecomicrobium litoralum which we studied utilize agar may be of ecological significance. It suggests that these marine strains may degrade algal polysaccharide materials in littoral regions. In addition, Prosthecomicrobium litoralum can utilize numerous sugars and some sugar alcohols, which comprise the degradation products of polysaccharides. These nutritional features may explain why enrichment with Ulva fronds was so successful. Prosthecomicrobium litoralum may also use dissolved organic carbon excreted by marine phytoplankton.

\section{ACKNOWLEDGMENTS}

This research was supported in part by grant GB-30313 from the National Science Foundation. J.B. was the recipient of an Australian-American Education Foundation Travel Grant (Fulbright). Completion of this work was aided by travel support for J.B. from the Potter Foundation.

We thank Jack Matches, Colleges of Fisheries, University of Washington, Seattle, for the use of his temperature gradient incubator. Manley Mandel kindly determined the DNA base compositions.

\section{LITERATURE CITED}

1. Bauld, J., and J. T. Staley. 1976. Planctomyces maris nov. sp., a marine isolate of the Planctomyces-Blastocaulis group of stalked, budding bacteria. J. Gen. Microbiol. 97:45-55.

2. Easterbrook, K. B. 1976. Spinin: the subunit protein of bacterial spinae. Can. J. Microbiol. 22:438-440.

3. Easterbrook, K. B., J. H. M. Willison, and R. W. Coombs. 1976. Arrangement of morphological subunits in bacterial spinae. Can. J. Microbiol. 22:619-629.

4. Hirsch, P. 1974. Budding bacteria. Annu. Rev, Microbiol. 28:391-444.

5. Leifson, E. 1964. Hyphomicrobium neptunium sp. n. Antonie van Leeuwenhoek J. Microbiol. Serol. 30:249-256.

6. McGregor-Shaw, J. B., K. B. Easterbrook, and R. P. McBride. 1973. A bacterium with echinulate (non-prosthecate) appendages. Int. J. Syst. Bacteriol. 23:267-270.

7. Moll, G., and R. Ahrens. 1970. Ein neuer Fimbrientyp. Arch. Mikrobiol. 70:361-368.

8. Poindexter, J. S. 1964. Biological properties and classification of the Caulobacter group. Bacteriol. Rev. 28:231295.

9. Staley, J. T. Prosthecomicrobium and Ancalomicrobium: new freshwater prosthecate bacteria. J. Bacteriol. 95:1921-1942.

10. Staley, J. T., and J. Bauld. 1981. The genus Planctomyces, p. 505-508. In M. P. Starr, H. Stolp, A. Balows, and H. G. Schlegel (ed.), The prokaryotes. SpringerVerlag, Berlin.

11. Staley, J. T., and M. Mandel. 1973. Deoxyribonucleic acid base composition of Prosthecomicrobium and Ancalomicrobium strains. Int. J. Syst. Bacteriol. 23:271-273. 